\title{
Competition and cooperation in the natural gas market: a game-theoretic demand-base analysis
}

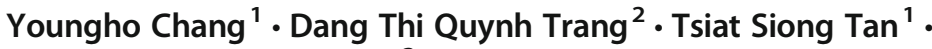 \\ Farhad Taghizadeh-Hesary ${ }^{3}$
}

Received: 12 August 2020 /Revised: 10 February 2021 / Accepted: 13 May 2021 /

Published online: 6 June 2021

(C) The Author(s), under exclusive licence to Springer-Verlag GmbH Germany, part of Springer Nature 2021

\begin{abstract}
This paper aims to explore various possibilities in the evolving global gas market by constructing game-theoretical models involving the major players: Russia and Qatar exporting gas to the Asia-Pacific and Europe, respectively. We explore a series of hypothetical scenarios based on competitive and collusive settings for the Asia-Pacific LNG market and based on Qatar's export route to the European gas market. The scenarios that are examined are (1) Russia as the follower and Qatar as the leader in a Stackelberg game; (2) Russia and Qatar as Cournot competitors; (3) collaboration between Russia and Qatar as bilateral monopolies; (4) Qatar exporting gas to European borders; (5) Qatar exporting gas to the last transit country; and (6) Qatar transporting gas to the Turkish border under a multi-pricing scheme. Demand is estimated under each scenario to simulate the respective export volumes, prices and quantities, and profit in each scenario. By exploring these market interactions, we find that it is essential for Russia to strike a deal with Qatar in the Asian market and accelerate their gas production in order to compete as an LNG market leader. Russia is likely to benefit more if it can link with Qatar to act as a monopoly on their segmental demand curve. On the other hand, Qatar's profit is expected to be higher under the scenario when Qatar sells all the gas to the last transit country as the sole demand point instead of passing through transit countries.
\end{abstract}

JEL classification $\mathrm{L} 13 \cdot \mathrm{L} 71 \cdot \mathrm{Q} 37 \cdot \mathrm{Q} 41$

Youngho Chang

yhchang@suss.edu.sg

1 Singapore University of Social Sciences, 463 Clementi Road, Singapore 599494, Singapore

2 Nanyang Technological University, Singapore, Singapore

3 Tokai University, Tokyo, Japan 


\section{Introduction}

The development of regional and global gas trade has been a story of rocketing growth, diversification, and rising flexibility in infrastructure planning. The USA is the largest natural gas producer, followed by Russia, Iran, Qatar, and China (BP, 2020). A shale gas boom in other countries in the world remains unlikely in years to come (Boersma 2013; UNCTAD 2018). Therefore, the gas outlook in the rest of the world largely depends on the gas demand and supply of major international players: the exporters (Qatar and Russia) and the importers (Europe and Asia-Pacific). ${ }^{1}$

The transport of Russian pipeline natural gas (PNG) to Europe through transit countries has faced recurring problems. In 2006 and 2009, Gazprom, the Russian gas exporter, disrupted supply to Ukraine and indirectly to Europe. In addition, in 2004, 2007, and 2010, the episodes of Russian-Belarusian gas disputes reiterate that gas supply security is a questionable notion (Kovacevic 2009). As it increasingly becomes Europe's interests to diversify into alternative supply sources (Ratner et al. 2013), potential entrants such as Qatar can obtain market share in the European pipeline gas market. Recently, the Deputy Energy Secretary of the United States discussed with and encouraged Doha to supply LNG to Europe, contesting Russia's gas dominance in the region (Reuters 2019).

Facing such a scenario, Russia increasingly adopts a strategic position as well. In 2019, the 1800-mile Power of Siberia pipeline started to deliver Russian natural gas to China (Xinhua 2019). There are also considerations on diversifying from PNG exports to liquefied natural gas (LNG) production on the Yamal Peninsula (Egging and Gabriel 2016; Kardas 2013a), catering to the Asia-Pacific market. LNG imports by Asia-Pacific have more than doubled (BP, 2013) in the last decade. Global LNG trade is expected to continue growing at a compound annual growth rate of $7.5 \%$ from 2011 to 2020 (Wood 2012). This growth is mostly attributed to fast-developing Asia-Pacific economies, which has consequently led to growing energy demand (Komiyama et al. 2005), driven mainly by China and South Korea (IGU 2018). However indeterminate, these demand projections are partially due to the interaction of various uncertainty effects, e.g., volatile prices, the multiple supply options, or Japan's restoration of the nuclear facilities (Ernst and Young 2013). Nonetheless, there is a general consensus that the rising Asia-Pacific LNG demand facilitates the likely entry of Russia as a supply competitor to Qatar. The share of Russia's LNG in the East Asian import basket is smaller than Qatar and Australia's shares, and it is mainly exported to Europe. However, Russia has a clear vision to develop its Eastern LNG projects to provide a bigger share of Asia-Pacific LNG imports. (Rasoulinezhad et al. 2019). Rasoulinezhad et al. (2019) found a negative nexus between geographical distance and LNG trade flows between Russia and East Asian economies. Any increase in geographical distance as a proxy for transportation cost lowers Russian LNG exports.

Natural gas pricing has been studied in the existing literature by multiple techniques. Gas prices are often examined by econometric time-series data, or the arithmetic Kalman-Filter method (see Neumann 2009; Zhu et al. 2018). The majority of the research, however, sees the gas market as an interconnected network and analyzes the behavior of different parties at each node. The World Gas Trade Model analyzes a

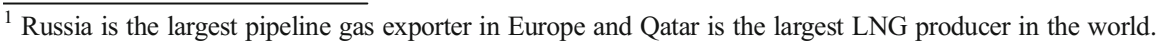


pattern of transporting routes and prices that minimize producers' rents within a competitive framework (Hartley and Medlock III 2009). The market structure of the World Gas Trade Model is dissimilar from that of the GASMOD model (see Holz et al. 2009; Xiao et al. 2019), the static version of the GASTALE model (see Lise and Hobbs 2009; Egging and Gabriel 2016), and the TIGER model by Lochner and Dieckhöner (2010). Game-theoretical settings among major gas players are also employed to analyze the market (Chernavsky and Eismont 2012; Dorigoni et al. 2009).

This paper aims to explore the various settings of Russia and Qatar exporting gas to the Asia-Pacific and Europe respectively and simulate the respective prices and quantities. The hypothetical scenarios are modelled using a game-theoretical framework are as follows: (1) Russia as the follower and Qatar as the leader in a Stackelberg game; (2) Russia and Qatar as Cournot competitors; (3) collaboration between Russia and Qatar as bilateral monopolies; (4) Qatar exporting gas to European borders; (5) Qatar exporting gas to the last transit country; and (6) Qatar transporting gas to the Turkish border under a multi-pricing scheme. Gas pricing models using game-theoretical simulations are scarce in the literature, and this study aims to contribute to the literature by estimating the profit outcomes of the proposed scenarios. The relationship between gas pricing under different market characteristics allows us to better understand Qatar and Russia's dynamics diversifying into Europe and Asia, respectively. To the authors' best knowledge, such a simulation with the given assumed scenarios has not been conducted before in the literature.

The paper is structured as follows. The next section reviews the literature on natural gas pricing. The "The analytical framework" section gives a detailed explanation of the models constructed. First, Russia enters the Asia-Pacific LNG market as a competitor to Qatar. In the short term, Qatar remains the dominant LNG exporter, and Russia acts as the follower under the Stackelberg model. In the longer term, the assumption that Russia expands LNG output and becomes an equivalent supplier to Qatar alters the interactions between the two suppliers into the Cournot game. While the Stackelberg and the Cournot models are non-cooperative games, the cooperative outcome of a profit-maximizing collusion is not omitted. In a separate hypothetical scenario, Qatar builds a pipeline via Jordan, Saudi Arabia, and Syria to supply PNG to Turkey and Europe. Cases examined include the possibilities of Qatar moving gas to European border, Qatar selling the entirety of their gas to Turkey, and Qatar transporting gas to the Turkish border and price discriminates between Europe and Turkey. From the derived framework, the "Analyses and discussions" section presents the results and discusses the intuitions behind them. Concluding remarks are encapsulated in the last section.

\section{Gas pricing models: literature review}

Gas pricing models have been developed extensively in multiple forms, broadly categorized under statistical, linear/non-linear programming, and game theoretical. Table 1 provides a brief description of some of the pricing models. These models give a more holistic understanding of gas prices and the gas market outlook.

The statistical approach studies correlations between key commodities prices, and identifies inter-regional price divergence/convergence (see Brown and Yucel 2009; 
Table 1 Natural gas pricing models

\begin{tabular}{ll}
\hline Methods & Studies \\
\hline Econometric & Brown and Yucel 2009 \\
& Zhu et al. 2018 \\
& Li et al. 2014 \\
& \\
$\begin{array}{c}\text { Kalman-Filter } \\
\text { Linear/non-linear } \\
\text { programming }\end{array}$ & $\begin{array}{c}\text { Aune et al. 2008 (FRISBEE } \\
\text { model) }\end{array}$
\end{tabular}

Key findings

Price is integrated across regional markets and the price of LNG appears the key factor rather than the price of oil.

Price convergence and separation between the USA and China during different time periods.

Evidence of convergence among UK, Taiwanese, Japanese, and Korean natural gas prices. The North American price does not converge. There is no fully integrated international gas market.

Convergence is shown in spot gas prices across Atlantic.

Trade over inter-continent is forecast to grow in the medium term and stability of current prices is expected to remain in main import regions

Netsbitt and Scotcher, 2009 (Spatial commodity)

Lise and Hobbs 2009 (GASTALE model)

Egging and Gabriel 2016 (Global Gas Model)

Price effects in a spatial network are never localized but the spatial system of inter-connected demand and supply appears to transmit the price effects.

Prices are determined by the interactions of accessibility to the market and the supplier's exercise of market power.

LNG appears to be Russia's preferred option of hedging for uncertain events. China is expected to eventually dominate the global gas market.

Egging et al. 2009 (World gas model)

Hartley and Medlock III 2009 (RICE World gas trade)

Holz et al. 2009 (GASMOD model)

\section{Zwart 2008 (NATGAS model)}

Lochner and Dieckhöner 2010 (TIGER model)

Orlov 2015 (CGE Model)

The formation of a gas cartel is expected to reduce global gas supply and raise the prices of gas by up to $22 \%$.

In the long term, the influence from Russia on the global market is limited as a result of competition.

In the future, Russia does not remain the dominant player in the European market. The Middle East remains a modest supplier of gas, and the European market appears to increasingly depend on LNG imports.

Lowering current prices appear to lead to higher prices in the future and boost social welfare.

European gas market is expected to be physically integrated well in the next decade.

The optimal domestic price in Russia is about $55 \%$ of the export netback price.

Game theoretical von Hirschhausen et al. 2005

Dorigoni et al. 2009

Chernavsky and Eismont 2012

By making Belarus an alternative transit country along with Ukraine, Russia is expected to increase profits significantly.

Under an active spot market, importers of LNG are expected to affect competition positively.

Russia appears to raise profit when a price of gas for Ukraine is linked to a transit tariff for Ukraine.

Popescu and Hurduzeu 2015 The European Union is advised to decrease import dependence on Russia and turn to alternatives.

Source: Authors' compilation

Neumann 2009; Zhu et al. 2018; Li et al. 2014). The linear (or non-linear) programming technique contains a collection of models within a dynamic network setting (see 
Lochner and Dieckhöner 2010; Orlov 2015; Aune et al. 2008; Nesbitt and Scotcher, 2009; Lise and Hobbs 2009; Egging et al. 2009; Hartley and Medlock III 2009; Holz et al. 2009; Zwart 2008). From the game-theoretical perspective, the impact of LNG producers' entry on competitively priced gas has been explored (see Dorigoni et al. 2009). The relationship between a pipeline gas exporter and transit countries is also addressed (see von Hirschhausen et al. 2005; Chernavsky and Eismont 2012).

This paper is interested in the application of game-theoretical models based on different market structures under competitive and collusive settings. Such pricing models are not new in the existing literature. However, the hypothetical scenarios proposed hereby between Russia and Qatar, as well as Qatar and transit countries, have never, in our knowledge, been studied before.

\section{The analytical framework}

This section constructs the framework for the interactions among gas suppliers in the European PNG market and the Asia-Pacific LNG market. In the Asia-Pacific LNG market, Russia and Qatar are presumed to undergo three stages: in the initial stage, Russia is the follower and Qatar is the leader in the Stackelberg game; in the medium term, Russia becomes the Cournot competitor of Qatar; in the long run, Russia and Qatar collaborate in a bilateral monopoly game with Asia-Pacific importers. In the European PNG market, Qatar can utilize three export routes to the prolific European gas market: Qatar exports gas to the European border through transit countries; Qatar delivers its gas up to the last country in transit (Turkey); and Qatar transports the gas to the Turkish border with a multi-pricing scheme. The section starts with the nomenclature before delving into the details.

\section{Nomenclature}

In general, the default market for LNG product is taken as Asia-Pacific. Therefore, all the uppercase subscripts only refer to the source country (either Russia or Qatar). The market for PNG, on the other hand, includes transit countries and Europe, so the subscripts compose of two letters, representing the source and destination countries respectively. Further variations are specified as and when needed.

$P_{l}$ Price of Asia-Pacific LNG (assume oil-delinking)

$Q_{l}$ Volume of LNG demanded from Asia-Pacific

$Q_{l i}$ Volume of LNG exported from country $i$ ( $i=R, Q$ for Russia, Qatar)

$l_{i}$ Unit liquefaction cost in export country $i$ ( $i=R, Q$ for Russia, Qatar)

$c_{i}^{e}$ Gas unit extraction cost in export country $i(i=R, Q$ for Russia, Qatar)

$m_{i}$ Miscellaneous unit exporting cost in export country $i$ ( $i=R, Q$ for Russia, Qatar)

$Q_{X} \mathrm{LNG}$ export volume from exporters

$P_{X} \mathrm{LNG}$ export price charged by exporters

$Q_{M} \mathrm{LNG}$ import volume by importers

$P_{M}$ LNG import price paid by importers

$P_{Q E}$ PNG export price that Qatar charged to Europe

$Q_{Q E} \mathrm{PNG}$ export volume from Qatar to Europe

$P_{E}$ PNG price that European actually pays 
$Q_{E}$ European PNG volume demanded that is met by Qatar

$P_{Q k}$ PNG export price that Qatar charged to transit country $k$ ( $k=t$ for Turkey)

$Q_{Q k}$ PNG export volume that Qatar exported to transit country $k$ ( $k=t$ for Turkey)

$P_{k}$ PNG price that transit country $k$ actually pays ( $k=t$ for Turkey)

$Q_{k}$ PNG volume demanded from transit country $k$ ( $k=t$ for Turkey)

$q_{k} \mathrm{PNG}$ own production of transit country $k$ ( $k=t$ for Turkey)

$c_{Q}$ PNG unit cost of production and transportation incurred by Qatar

$c_{k T}$ Unit cost of transporting gas incurred by transit country $k$ ( $k=t$ for Turkey)

$\tau_{k}$ Transit fee charged by transit country $k$ per unit of gas volume ( $k=t$ for Turkey)

\section{Russia for the Asia-Pacific via LNG}

The rationale of gas-to-gas competition in the demand curve is elaborated under the analysis following the framework. First, the inverse curve of residual demand for LNG in the Asia-Pacific is assumed up to 2020, served by Qatar and Russia, is:

$$
P_{l}=a_{l}-b_{l} Q_{l}
$$

where $a_{l}$ and $b_{l}$ are the parameters.

Marginal cost of exporting gas of country $i$ is: ${ }^{2}$

$$
M C_{l i}=m_{i}+\left(l_{i}+c_{i}^{e}\right) Q_{l i}
$$

The capacity of LNG export of Russia determines the game between Russia and Qatar and in turn it appears to heavily rely on the commissioning of some gas fields such as Shtokmanovskoye, Vladivostok, and Yamal in the country. The three stages are constructed according to a progressive development of the market towards a concentrated structure.

Stage 1: Russia is the follower in the Stackelberg game with Qatar

The inverse demand function supplied by Russia and Qatar is:

$$
P_{l}=a_{l}-b_{l}\left(Q_{l R}+Q_{l Q}\right)
$$

The profit function of Russia is given by the difference between how much she receives from selling $\mathrm{LNG}\left\lfloor a_{l}-b_{l}\left(Q_{l R}+Q_{l Q}\right)\right\rfloor Q_{l R}$ and her cost of selling gas, inclusive of liquefaction, cost of extracting the gas, and miscellaneous cost, $m_{R} Q_{l R}+\left(l_{R}+c_{R}^{e}\right) \frac{Q_{l R}^{2}}{2}$ or:

$$
\pi_{l R}=P_{l} Q_{l R}-\int_{0}^{Q_{l R}} M C_{l R} d Q_{l R}=\left[a_{l}-b_{l}\left(Q_{l R}+Q_{l Q}\right)\right] Q_{l R}-m_{R} Q_{l R}-\left(l_{R}+c_{R}^{e}\right) \frac{Q_{l R}^{2}}{2}
$$

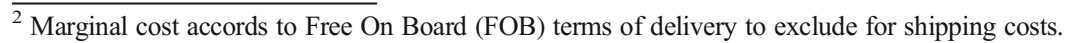


Russia chooses the optimal export quantity $Q_{l R}^{*}$ such that the marginal profit of Russia from selling additional gas is zero, i.e., $\frac{d \pi_{l R}}{d Q_{I R}}=0$. Thus, the optimal exporting volume for Russia is expressed as follows:

$$
Q_{l R}^{*}=\frac{a_{l}-b_{l} Q_{l Q}-m_{R}}{2 b_{l}+l_{R}+c_{R}^{e}}
$$

The profit function of Qatar is given by the difference between how much she receives from selling LNG $\left\lfloor a_{l}-b_{l}\left(Q_{l Q}+Q_{l R}\right)\right\rfloor Q_{l Q}$ and her cost of liquefying as well as extracting gas and miscellaneous cost $m_{Q} Q_{l Q}+\left(l_{Q}+c_{Q}^{e}\right) \frac{Q_{l Q}^{2}}{2}$

or:

$$
\pi_{l Q}=P_{l} Q_{l Q}-\int_{0}^{Q_{l Q}} M C_{l Q} d Q_{l Q}=\left[a_{l}-b_{l}\left(Q_{l Q}+Q_{l R}\right)\right] Q_{l Q}-m_{Q} Q_{l Q}-\left(l_{Q}+c_{Q}^{e}\right) \frac{Q_{l Q}^{e}}{2}(6)
$$

As the leader, Qatar takes the volume of LNG exported by Russia as given. Substituting Eq. (5) into Eq. (6) gives:

$$
\pi_{l Q}=\left[a_{l}-b_{l}\left(Q_{l Q}+\frac{a_{l}-b_{l} Q_{l Q}-m_{R}}{2 b_{l}+l_{R}+c_{R}^{e}}\right)\right] Q_{l Q}-m_{Q} Q_{l Q}-\left(l_{Q}+c_{Q}^{e}\right) \frac{Q_{l Q}^{2}}{2}
$$

The optimal export volume for Qatar is expressed as follows:

$$
Q_{l Q}^{*}=\frac{\left(a_{l}-m_{Q}\right)\left(2 b_{l}+l_{R}+c_{R}^{e}\right)-b_{l}\left(a_{l}-m_{R}\right)}{\left(2 b_{l}+l_{R}+c_{R}^{e}\right)\left(2 b_{l}+l_{Q}+c_{Q}^{e}\right)-2 b_{l}^{2}}
$$

From Eqs. (3), (5), and (8):

$$
P_{l}^{*}=a_{l}-b_{l}\left(Q_{l R}^{*}+Q_{l Q}^{*}\right)
$$

Stage 2: Russia and Qatar in the Cournot game

In the medium run, when LNG production of Russia ramps up, Russia gets a larger share in the Asia-Pacific market; the Stackelberg game becomes the Cournot game. From Eq. (5), the best response function for Qatar can be derived in the same way to get:

$$
Q_{l Q}^{*}=\frac{a_{l}-b_{l} Q_{l R}-m_{Q}}{2 b_{l}+l_{Q}+c_{Q}^{e}}
$$


Substitute Eq. (10) into Eq. (5) gives:

$$
Q_{l R}^{*}=\frac{\left(a_{l}-m_{R}\right)\left(2 b_{l}+l_{Q}+c_{Q}^{e}\right)-b_{l}\left(a_{l}-m_{Q}\right)}{\left(2 b_{l}+l_{R}+c_{R}^{e}\right)\left(2 b_{l}+l_{Q}+c_{Q}^{e}\right)-b_{l}^{2}}
$$

Similarly:

$$
Q_{l Q}^{*}=\frac{\left(a_{l}-m_{Q}\right)\left(2 b_{l}+l_{R}+c_{R}^{e}\right)-b_{l}\left(a_{l}-m_{R}\right)}{\left(2 b_{l}+l_{R}+c_{R}^{e}\right)\left(2 b_{l}+l_{Q}+c_{Q}^{e}\right)-b_{l}^{2}}
$$

From Eqs. (3), (11a), and (11b):

$$
P_{l}^{*}=a_{l}-b_{l}\left(Q_{l R}^{*}+Q_{l Q}^{*}\right)
$$

Stage 3: Russia and Qatar in a bilateral monopoly game

The above two stages are formulated on the grounds that there is no cooperation between Russia and Qatar. If Russia and Qatar form a cartel and become a sole exporter (i.e., a virtual monopoly), Asia-Pacific importers are assumed to unite and become a sole buyer (i.e., a virtual monopsony).

For exporters: The total marginal cost is the horizontal summation of two members' marginal costs.

$$
\begin{gathered}
M C_{l R}=m_{R}+\left(l_{R}+c_{R}^{e}\right) Q_{l R} \rightarrow Q_{l R}=\frac{1}{l_{R}+c_{R}^{e}}\left(M C_{l R}-m_{R}\right) \\
M C_{l Q}=m_{Q}+\left(l_{Q}+c_{Q}^{e}\right) Q_{l Q} \rightarrow Q_{l Q}=\frac{1}{l_{Q}+c_{Q}^{e}}\left(M C_{l Q}-m_{Q}\right) \\
Q_{l}=Q_{l R}+Q_{l Q}=\frac{1}{l_{R}+c_{R}^{e}}\left(M C_{l R}-m_{R}\right)+\frac{1}{l_{Q}+c_{Q}^{e}}\left(M C_{l Q}-m_{Q}\right)
\end{gathered}
$$

As $M C_{R}=M C_{Q}=M C_{l}$ :

$$
Q_{l}=\left(\frac{1}{l_{R}+c_{R}^{e}}+\frac{1}{l_{Q}+c_{Q}^{e}}\right) M C_{l}-\frac{m_{R}}{l_{R}+c_{R}^{e}}-\frac{m_{R}}{l_{Q}+c_{Q}^{e}}
$$


The supply curve of exporters is expressed as follows:

$$
P_{l}=M C_{l}=\frac{Q_{l}+\left(\frac{m_{R}}{l_{R}+c_{R}^{e}}+\frac{m_{Q}}{l_{Q}+c_{Q}^{e}}\right)}{\frac{1}{l_{R}+c_{R}^{e}}+\frac{1}{l_{Q}+c_{Q}^{e}}}
$$

From Eq. (1): $M R_{l}=a_{l}-2 b_{l} Q_{l}$

The profit-maximization problem for exporter is conditioned upon

$$
M C_{l}=M R_{l}
$$

Equation (18) gives the optimal export volume, which is denoted subsequently as $Q_{X}^{*}$.

$$
Q_{X}^{*}=\frac{\left(a_{l}-m_{R}\right)\left(l_{Q}+c_{Q}^{e}\right)+\left(a_{l}-m_{Q}\right)\left(l_{R}+c_{R}^{e}\right)}{\left(l_{Q}+c_{Q}^{e}\right)\left(l_{R}+c_{R}^{e}\right)+2 b\left(l_{Q}+c_{Q}^{e}+l_{R}+c_{R}^{e}\right)}
$$

From Eqs. (1) and (19), the wholesale price exporters want to charge is:

$$
P_{X}^{*}=a_{l}-b_{l} Q_{X}^{*}
$$

For importers: Equation (1) is taken to be the marginal revenue product curve from importing LNG: $P_{l}=M R P_{l}$ while the supply curve of LNG is also the upward sloping marginal cost curve of exporting LNG (Eq. 17). From this supply curve, total cost of importing LNG is given by:

$$
T C_{l}=P_{l} Q_{l}=\left[\frac{Q_{l}+\left(\frac{m_{R}}{l_{R}+c_{R}^{e}}+\frac{m_{Q}}{l_{Q}+c_{Q}^{e}}\right)}{\frac{1}{l_{R}+c_{R}^{e}}+\frac{1}{l_{Q}+c_{Q}^{e}}}\right] Q_{l}
$$

As importers have to pay a higher price not only for the additional unit of LNG imported but also for all the previous quantity, the marginal factor cost of importing LNG is higher than the price implied in the marginal cost curve. Marginal factor cost is expressed as:

$$
M F C_{l}=\frac{d T C_{l}}{d Q_{l}}=\frac{2 Q_{l}+\left(\frac{m_{R}}{l_{R}+c_{R}^{e}}+\frac{m_{Q}}{l_{Q}+c_{Q}^{e}}\right)}{\frac{1}{l_{R}+c_{R}^{e}}+\frac{1}{l_{Q}+c_{Q}^{e}}}
$$


Monopsonist's profit-maximizing condition is

$$
M F C_{l}=P_{l}
$$

From Eqs. (1), (22), and (23), optimal import volume is obtained, which is hereby denoted as $Q_{M}^{*}$.

$$
Q_{M}^{*}=\frac{\left(a_{l}-m_{R}\right)\left(l_{Q}+c_{Q}^{e}\right)+\left(a_{l}-m_{Q}\right)\left(l_{R}+c_{R}^{e}\right)}{2\left(l_{Q}+c_{Q}^{e}\right)\left(l_{R}+c_{R}^{e}\right)+b\left(l_{Q}+c_{Q}^{e}+l_{R}+c_{R}^{e}\right)}
$$

From Eqs. (1) and (24), the wholesale price monopsonist wants to pay is:

$$
P_{M}^{*}=\frac{Q_{M}^{*}+\left(\frac{m_{R}}{l_{R}+c_{R}^{e}}+\frac{m_{Q}}{l_{Q}+c_{Q}^{e}}\right)}{\frac{1}{l_{R}+c_{R}^{e}}+\frac{1}{l_{Q}+c_{Q}^{e}}}
$$

In summary: Wholesale price lies in the range of $\left(P_{M}^{*}, P_{X}^{*}\right)$ and similarly, wholesale volume in the range of $\left(Q_{X}^{*}, Q_{M}^{*}\right)$. The eventual wholesale price and volume, however, depend on the bargaining power of each party.

The minimum price that the monopolist is able to accept is such that the producer surplus is equal to 0 or the area below the exporting price and above the marginal cost curve is 0 . This condition is expressed formulaically as:

$$
P_{\min } Q_{X}^{*}-\int_{0}^{Q_{X}^{*}} M C_{l} d Q_{l}=0 \rightarrow P_{\min }=\frac{\int_{0}^{Q_{X}^{*}} M C_{l} d Q_{l}}{Q_{X}^{*}}
$$

From Eqs. (17) and (26):

$$
P_{\min }=\frac{Q_{X}^{*}+2\left(\frac{m_{R}}{l_{R}+c_{R}^{e}}+\frac{m_{Q}}{l_{Q}+c_{Q}^{e}}\right)}{2\left(\frac{1}{l_{R}+c_{R}^{e}}+\frac{1}{l_{Q}+c_{Q}^{e}}\right)}
$$

The maximum price that the monopsonist can pay is such that the consumer surplus is equal to 0 or the area under the demand curve and above the importing price is 0 . In other words, the following must hold:

$$
\int_{0}^{Q_{M}^{*}} P_{l} d Q_{l}-P_{\max } Q_{M}^{*}=0 \rightarrow P_{\max }=\frac{\int_{0}^{Q_{M}^{*}} P_{l} d Q_{l}}{Q_{M}^{*}}
$$


From Eqs. (1) and (28):

$$
P_{\max }=a_{l}-b_{l} \frac{Q_{M}^{*}}{2}
$$

\section{Qatar for Europe via gas pipeline}

A model is established where Qatar PNG passes through $n$ transit countries $(n>1)$ before going into Europe. A gas pipeline proposed in the hypothetical setting assumes that Turkey is the last country in transit before the gas is delivered to other nations in Europe.

It is assumed that Qatar can exert market power on the residual demand curve she faces in Europe $Q_{E}\left(P_{E}\right)$. The domestic production of a transit country $k$ is assumed to be much smaller than the total demand for gas of the transit country, or $q_{k}<<Q_{k}\left(P_{k}\right)$, so that Qatar has some market power over these transit countries. With these in mind, Qatar can sell PNG to Turkey and the rest of Europe in three following ways:

Case 1: Qatar transports gas up to the European border

Qatar's profit is expressed as follows:

$$
\pi_{Q}=\left(P_{Q E}-c_{Q}-\sum_{k=1}^{n} \tau_{k}\right) Q_{Q E}\left(P_{Q E}\right)+\sum_{k=1}^{n}\left(P_{Q k}-c_{Q}\right)\left(Q_{Q k}\left(P_{Q k}\right)-q_{k}\right)
$$

In which the first product denotes Qatar's profit derived from selling gas to Europe, taking into account transit fees, and the second product refers to her profit from selling gas to a transit country $k$.

To maximize Qatar's profit derived from supplying gas to Europe with respect to price under an exogenously determined transportation tariff, the necessary condition is that the marginal profit from selling more gas is zero, i.e., $\frac{\partial \pi_{Q}}{\partial P_{Q E}}=0$. This leads to the following condition:

$$
Q_{Q E}+\left(P_{Q E}-c_{Q}-\sum_{k=1}^{n} \tau_{k}\right) Q_{Q E}^{\prime}=0
$$

From Eq. (31), the optimal price of Qatar's gas supplied to Europe is dependent on a transportation tariff determined by transit countries $P_{Q E}^{*}\left(\tau_{1}, \tau_{2}, \ldots, \tau_{n}\right)$ can be calculated. Also, the implicit function rule gives:

$$
\frac{d P_{Q E}}{d \tau_{k}}=\frac{Q_{Q E}^{\prime}}{2 Q_{Q E}^{\prime}+\left(P_{Q E}-c_{Q}-\sum_{k=1}^{n} \tau_{k}\right) Q_{Q E}^{\prime \prime}}
$$

From which, it follows from a linear demand function:

$$
Q_{E}=a_{E}-b_{E} P_{E}
$$


As this demand is satisfied by Qatar and the price paid by Europe is also what Qatar receives, $Q_{E}=Q_{Q E}$ and $P_{E}=P_{Q E}$. Hence, $Q_{Q E}^{\prime}=-b_{E}, Q_{Q E}^{\prime}=0$, or $\frac{d P_{Q E}}{d \tau_{k}}=\frac{1}{2}$

For a transit country, the profit derived from transporting gas to Europe is given as follows:

$$
\pi_{k}=\left(\tau_{k}-c_{k T}\right) Q_{Q E}\left(P_{Q E}^{*}\left(\tau_{1}, \tau_{2}, \ldots, \tau_{n}\right)\right)
$$

A transit country $i$ sets the tariff such that the marginal profit from the extra tariff is zero, i.e., $\frac{\partial \pi_{k}}{\partial \tau_{k}}=0$ which yields:

$$
Q_{Q E}\left(P_{Q E}^{*}\left(\tau_{1}, \tau_{2}, \ldots, \tau_{n}\right)\right)+\left(\tau_{k}-c_{k T}\right) Q_{Q E}^{\prime} \frac{\partial P_{Q E}^{*}\left(\tau_{1}, \tau_{2}, \ldots, \tau_{n}\right)}{\partial \tau_{k}}=0
$$

From Eqs. (31) and (35), Qatari PNG price exported to Europe is deduced as:

$$
P_{Q E}^{*}=\frac{1}{2}\left(\frac{a_{E}}{b_{E}}+c_{Q}+\sum_{k=1}^{n} \tau_{k}\right)
$$

Substituting Eq. (36) into Eq. (35) gives the optimal transit fee:

$$
\tau_{k}^{*}=\frac{1}{2}\left(\frac{a_{E}}{b_{E}}-c_{Q}+c_{k T}-\sum_{k \neq j} \tau j\right)
$$

From Eqs. (36) and (37), it follows that the price that Qatar charges Europe is expressed as:

$$
P_{Q E}^{*}=\frac{1}{4}\left[\frac{a_{E}}{b_{E}}(2+n)+c_{Q}(2-n)+\sum_{k=1}^{n} c_{k T}-(n-1) \sum_{k=1}^{n} \tau_{k}\right]
$$

The price of Qatari gas delivered to transit countries is determined from maximizing the profit from gas supplies to transit countries for Qatar under Qatar's monopoly on the residual demand portion of transit countries $Q_{k}=a_{k}-b_{k} P_{k}$. Therefore, from Eq. (30), Qatar chooses the optimal price such that the marginal profit from selling extra volumes is zero or $\frac{\partial \pi_{Q}}{\partial P_{k}}=0$. The optimal price that Qatar sets for the transit countries and the optimal quantity of gas sold are as follows:

$$
\begin{gathered}
P_{Q k}^{*}=\frac{a_{k}-q_{k}+b_{k} c_{Q}}{2 b_{k}} \\
Q_{Q k}^{*}=\frac{1}{2}\left(a_{k}+q_{k}-b_{k} c_{Q}\right)
\end{gathered}
$$


Case 2: Qatar sells all the gas to the last transit country, Turkey. The preceding transit countries are omitted for simplicity.

For this case, no problems exist in transporting natural gas to Europe from Russia as the risks are borne by Turkey. Qatar acts as the leader in the Stackelberg game with Turkey. The price of gas sold to Turkey is $P_{Q t}$, and the price of gas sold within this country is $P_{t}=P_{Q t}$. Assume that Turkey knows the European demand curve for Qatari gas. Her profit function would be:

$$
\pi_{t}=\left(P_{E}-P_{Q t}-c_{t T}\right) Q_{E}\left(P_{E}\right)
$$

Turkey maximizes profit if the marginal profit from selling additional volumes to Europe is zero, i.e., $\frac{\partial \pi_{t}}{\partial P_{E}}=0$. Thus, the following condition must hold:

$$
Q_{E}\left(P_{E}\right)+\left(P_{E}-P_{Q t}-c_{t T}\right) Q_{E}^{\prime}\left(P_{E}\right)=0
$$

From Eq. (42), $P_{E}\left(P_{Q t}\right)$ is obtained:

$$
P_{E}=\frac{1}{2}\left(\frac{a_{E}}{b_{E}}+P_{Q t}+c_{t T}\right)
$$

Qatar's profit from exporting gas to Turkey, taking into account consumption on her own and export to Europe, is:

$$
\pi_{Q}=\left(P_{Q t}-c_{Q}\right)\left(Q_{E}\left(P_{E}\left(P_{Q t}\right)\right)+Q_{Q t}\left(P_{Q t}\right)-q_{t}\right)
$$

where the gas volume sold to Turkey consists of those sold to Europe $Q_{E}\left(P_{E}\left(P_{Q t}\right)\right)$ and those that Turkey demands $Q_{Q t}\left(P_{Q t}\right)$ on top of what Turkey produces domestically $q_{t}$.

The volume of gas maximizing profits for Qatar to sell it to Turkey is given by:

$$
P_{Q t}^{*}=\frac{a_{E}+2 a_{t}-2 q_{t}+\left(c_{Q}-c_{t T}\right) b_{E}+2 c_{Q} b_{t}}{2\left(b_{E}+2 b_{t}\right)}
$$

From Eqs. (43) and (45), the optimal price charged to Europe is expressed as:

$$
P_{E}^{*}=\frac{\frac{3}{2} a_{E} b_{E}+\frac{1}{2}\left(c_{Q}+c_{t T}\right) b_{E}^{2}+b_{E} b_{t}\left(c_{Q}+c_{t T}\right)+b_{E}\left(a_{t}-q_{t}\right)+2 a_{E} b_{t}}{2 b_{E}\left(b_{E}+2 b_{t}\right)}
$$

Case 3: Qatar delivers European gas to the Turkish border and applies price discrimination to Europe and Turkey.

The gas price that European countries pay is assumed to be $P_{E}=P_{Q E}+\tau_{t}$ where $\tau_{t}$ is the transportation tariff charged by Turkey. Qatar's profit function is given as below:

$$
\pi_{Q}=\left(P_{Q E}-c_{Q}\right) Q_{Q E}\left(P_{Q E}+\tau_{t}\right)+\left(P_{t}-c_{Q}\right)\left(Q_{Q t}\left(P_{Q t}\right)-q_{t}\right)
$$


where the first product denotes Qatar's profit from selling gas to Europe at an effective price of $P_{Q E}+\tau_{t}$ and the second term is her profit from selling gas to Turkey.

Turkey's profit from transporting gas from Qatar to Europe is:

$$
\pi_{t}=\left(\tau_{t}-c_{t T}\right) Q_{Q E}\left(P_{Q E}+\tau_{t}\right)
$$

In order for Turkey to maximize her profit, the following condition must hold true:

$$
Q_{Q E}\left(P_{Q E}+\tau_{t}\right)+\left(\tau_{t}-c_{t T}\right) Q_{Q E}^{\prime}\left(P_{Q E}+\tau_{t}\right)=0
$$

Equation (49) defines the optimal transportation tariff $\tau_{t}^{*}\left(P_{Q E}\right)$ as:

$$
\tau_{t}^{*}\left(P_{Q E}\right)=\frac{1}{2}\left(\frac{a_{E}}{b_{E}}-P_{Q E}+c_{t T}\right)
$$

Knowing this function $\tau_{t}^{*}\left(P_{Q E}\right)$, Qatar maximizes her profit from gas supplies to Europe, which yields the following condition:

$$
Q_{Q E}\left(P_{Q E}+\tau_{t}\left(P_{Q E}\right)\right)+\left(P_{Q E}-c_{Q}\right) Q_{E}^{\prime}\left(1+\tau_{t}^{\prime}\left(P_{Q E}\right)\right)=0
$$

Equation (51) defines the optimal price for Qatar, $P_{Q E}$ as:

$$
P_{Q E}^{*}=\frac{1}{2}\left(\frac{a_{E}}{b_{E}}+c_{Q}-c_{t T}\right)
$$

From this, the remaining variables are derived as:

$$
\begin{gathered}
\tau_{t}^{*}=\frac{1}{4}\left(\frac{a_{E}}{b_{E}}-c_{Q}+3 c_{t T}\right) \\
P_{E}^{*}={ }_{4}^{1}\left(3 \frac{a_{E}}{b_{E}}+c_{Q}+c_{t T}\right) \\
P_{Q t}^{*}=\frac{1}{2}\left(\frac{a_{t}}{b_{t}}+c_{Q}-c_{t T}\right)
\end{gathered}
$$




\section{Analyses and discussions}

In this section, the workability of the framework is tested. Every scenario is studied according to its peculiarities and outcomes. The starting point of the analyses is the estimation of the demand curve. The increase in gas demand in both Asia-Pacific and Europe is the foremost condition for ensuring new players' entrance in the exporting market.

\section{Estimation of demand curves}

\section{The demand curve for the Asia-Pacific LNG market}

Gas demand has been continuously growing in the last decade, as shown in Table 2 and Fig. 1; hence, the assumption of larger demand in subsequent periods is justified. Particularly, LNG imports for the key Asia-Pacific market have risen from $162.2 \mathrm{bcm}$ in 2008 to $334.1 \mathrm{bcm}$ in 2019 (BP, 2020), increasing approximately $106 \%$ over 10 years. In the low-demand case, demand growth for the Asia-Pacific region is estimated to be $3.9 \%$ per annum from 2010 to 2025 (IEA 2010), with LNG imports growing from $178 \mathrm{bcm}$ in 2010 to $280 \mathrm{bcm}$ in 2025 . This conservative estimation has already been exceeded as of 2018 but will be considered for completeness. Under the high-demand case, demand growth for Korea and Taiwan is taken as $25 \%$ over the low demand case (IEA 2011). Following IEA, in this paper, demand is constructed to grow at $3.9 \%$ in the low-demand case, $5 \%$ in the business-as-usual (BAU) for countries other than Korea and Taiwan, and $25 \%$ for Korea and Taiwan under high-demand assumption.

Asian utilities have increasingly gained exposure to the US and Canada equity by acquiring more assets in the US and Canadian shale oil and gas companies (Henderson 2012). Thus, Asian-Pacific importers might bargain for a change in the pricing mechanism and challenge the rationale for oil-linked LNG contracts. At the same time,

Table 2 LNG at JCC spot rate and LNG long-term import price in 2000-2011

\begin{tabular}{lllll}
\hline Year & LNG at JCC parity & Japanese LNG import price & Average spread & Spread (\%) \\
\hline 2000 & 4.89 & 4.7 & 1.02 & $22 \%$ \\
2001 & 4.27 & 4.61 & 0.56 & $12 \%$ \\
2002 & 4.36 & 4.28 & 0.71 & $16 \%$ \\
2003 & 5.05 & 4.79 & 0.63 & $13 \%$ \\
2004 & 6.37 & 5.19 & 1.24 & $24 \%$ \\
2005 & 9.02 & 6.02 & 2.51 & $42 \%$ \\
2006 & 11.08 & 7.12 & 6.14 & $86 \%$ \\
2007 & 12.3 & 7.74 & 5.02 & $65 \%$ \\
2008 & 16.92 & 12.66 & 11.16 & $88 \%$ \\
2009 & 10.92 & 9.04 & 7.23 & $80 \%$ \\
2010 & 13.83 & 10.9 & 6.15 & $56 \%$ \\
2011 & 19.07 & 14.78 & 7.36 & $50 \%$ \\
\hline
\end{tabular}




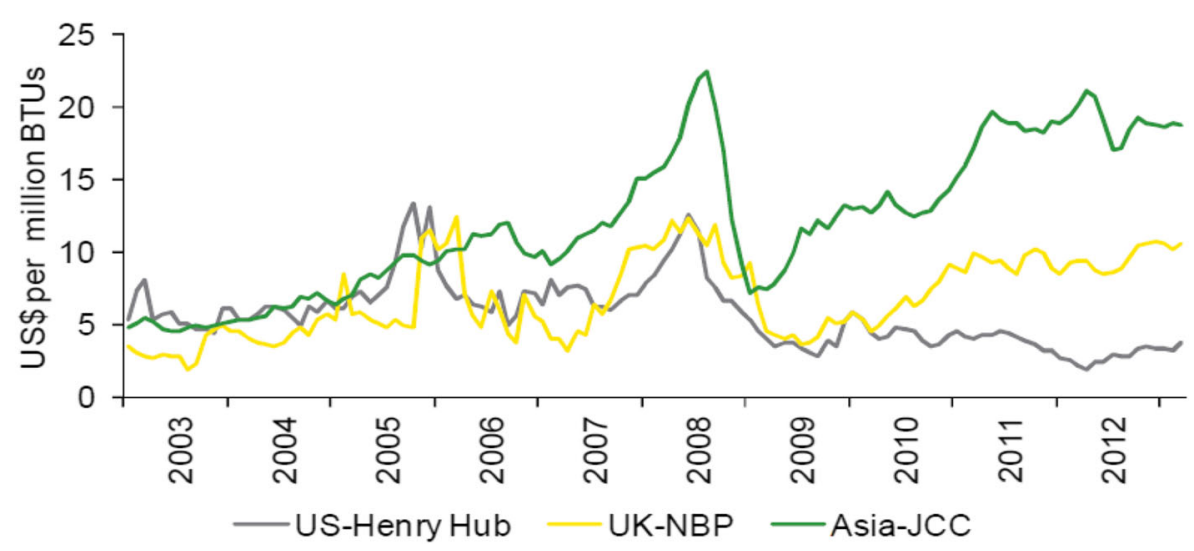

Fig. 1 Global natural gas prices (monthly averages). Source: Ernst and Young (2013)

the changing role of the USA from importer to exporter would contribute to the popularity of short-term LNG trading (Rogers 2012). As a matter of fact, short-term trading has been rising rapidly (Brito and Hartley 2007). Going forward, a steady migration from oil-linked pricing to more hub-based pricing is expected to prevail when the supply shortage in LNG has been overcome. With these, the demand curve of the Asia-Pacific countries' residual demand for Qatar and Russia is constructed from two data points: one data point from 2012 and the other from 2020 estimates. The assumptions on volumes and prices are presented in Table 3.

\section{Demand curve for the European gas market}

Today, the gas import volume to Europe is expected to reach $70 \%$ by 2030 , due to the coincidence of increased demand and a decreased supply in natural gas (ORSAM, 2011). Natural gas production in Europe is expected to be dwindling from $275 \mathrm{bcm}$ in

Table 3 Residual Asian-Pacific gas market in 2012 and assumptions for 2020

\begin{tabular}{lll}
\hline & $2012 *$ & $2020^{* *}$ \\
\hline Residual import demand (bcm) & & 10.79 \\
China & 7.3 & 24.78 \\
India & 16.1 & 48.17 \\
Japan & 32.6 & 102.52 \\
South Korea & 17.2 & 48.88 \\
Taiwan & 7.9 & 0.74 \\
Thailand & 0.3 & $7.74 * * *$ \\
LNG import price $(\$ / \mathrm{mmBtu})$ & 15 & \\
\hline
\end{tabular}

*Data for 2012 are based on BP Statistical Review

**Data for 2020 are estimated based on 5\% growth for countries other than Korea and Taiwan and $25 \%$ for Korea and Taiwan

***Das (2011) estimates that the break-even cost of natural gas post-regasification at a Japanese or Korean LNG facility could be $\$ 7.17 / \mathrm{mmBtu}$ 
2010 , to $226 \mathrm{bcm}$ in 2020 , to $203 \mathrm{bcm}$ in 2030 while consumption is expected to grow strongly from $554 \mathrm{bcm}$ in 2010, to $635 \mathrm{bcm}$ in 2020, to $667 \mathrm{bcm}$ in 2030 (Egging et al. 2009).

Meanwhile, Russia has been the largest exporter of natural gas to Europe. There have been growing concerns in recent years in Europe on the reliability of Russian gas supply. About $90 \%$ of Russian pipeline gas export to Europe passes through Ukraine and Belarus. Gas supply interruptions, due to conflicts in the transit countries, have reckoned that energy security cannot be affirmed with this one-sided dependence on Russian gas imports. To reduce Europe's vulnerabilities to this high dependency on Russia and the transit countries, the diversification of import sources and routes are imperative. $^{3}$

Possessing the third largest natural gas reserves in the world, Qatar has competitive goals in ensuring Europe's gas supply security, and adopts a harmonious approach in foreign affairs. Qatar is well-situated in shifting her production profile from LNG to pipeline gas to Europe, and such a potential project is a feasible one that provides supply route diversification to Europe and allays the dependency problem.

The modelling of pipeline gas from Qatar to Europe is currently still underexplored, but available studies show that changes in Europe's supply situation would not be major in the short run (see Holz et al. 2009). To construct the demand curve faced by Qatar in the European market, it is acknowledged that a gas pipeline from Qatar to Russia is non-existent now. Hence, projections would employ two data points in the future. Assuming 2020 and 2025 are chosen, the stipulated volumes and prices are shown in Table 4.

\section{Results}

The cost assumptions used are mainly transferred from Cournot-Gandolphe et al. (2003), Stauffer (1995), and Brito and Sheshinski (1997). While costs have fluctuated over the years, in the light of the COVID-19 pandemic, Asian LNG prices have most recently fallen to $\$ 2.70 / \mathrm{mmBtu}$ (Reuters 2020) and the Henry Hub pipeline gas price stands at about $\$ 1.75$ as of June 2020 (EIA, 2020), and these prices have been said to be close to zero profit (World Oil 2020), i.e., total cost. As such, the cost assumptions were drawn from studies, albeit dated, that most relevantly reflect the costs today. For example, with the adopted assumptions, LNG costs $(\$ 0.65+\$ 1.05+\$ 0.60+0.40=$ $\$ 2.70$ ) the same as the current LNG price at close to no profit. Various metrics are presented in Table 5 .

This part describes the three stages when Russia enters the Asia-Pacific LNG market and three cases when Qatar joins the gas pipeline exporting market to European countries. A summary of the results is shown in Table 6 .

\footnotetext{
${ }_{3}^{3}$ Many project developments have aimed at increasing pipeline sources and routes alongside Russia via Ukraine and Belarus in place or in consideration. The Nord Stream Pipeline Project omits Ukraine and Belarus as transit countries. The Nabucco pipeline, the South Stream, and the Southern Gas Corridor also carry central Asia/Caspian gas to Europe. The Trans-Adriatic pipeline, Turkey-Greece-Italy pipeline, GALSI project, and Skanled Project are some examples among others.
} 
Table 4 Residual European gas market in 2020 and 2025

\begin{tabular}{lll}
\hline & 2020 & 2025 \\
\hline European import demand (bcm) & $10^{* * * *}$ & $15 * * * *$ \\
LNG import price $(\$ / \mathrm{mmBtu})$ & $11 * * * * *$ & $10 * * * * *$ \\
\hline
\end{tabular}

****Assuming $10 \mathrm{bcm}$ is exported initially via the 20-bcm proposed pipe in the base case and this $10 \mathrm{bcm}$ is increased to $15 \mathrm{bcm} 5$ years later

*****These prices are close approximates (see Egging et al. 2009)

\section{Russia for Asia-Pacific via LNG stage 1}

First, the case where Russia is a new entrant and is treated as the follower in the Stackelberg game with Qatar is considered. The list of LNG projects in Russia is presented in Table 7. This possibility is calibrated with a time span of 3-5 years. Optimal LNG price in Asia-Pacific is \$9.46 per million British thermal units (mmBtu). The optimal exporting volumes for Russia and Qatar are $50.39 \mathrm{bcm}$ and $137.99 \mathrm{bcm}$ respectively.

This stage is based on awaiting the Russian gas fringe companies getting full approvals that would allow them to export their products to the Asian gas market and terminate Gazprom's long-standing monopoly. ${ }^{4}$ The short-term interaction between Russia and Qatar is classified as the Stackelberg game because the new law from Russia is expected to slowly take effect with Novatek and Rosneft completing their LNG export projects. ${ }^{5}$ A closer look into Russian LNG projects to Asia is given in Table 8. If initially, when some LNG projects start to be exported in 2018, total maximum LNG volume to Asia approximates 53 million tons (MT) or $71.62 \mathrm{bcm}^{6}$ This is larger than the optimal quantity 50.39 bcm that Russia should sell to the AsiaPacific market. The result, therefore, does not exceed the full potential of Russia in the short-run. Following the Stackelberg game, it is noticeable that Qatar can actually export up to $137.99 \mathrm{bcm}$, and Russia pockets a profit of $\$ 10,466,468,182$, three times lower than Qatar's \$34,149,030,787.

\section{Russia for Asia-Pacific via LNG stage 2}

By 2020, in order to capture a larger share of the Asia-Pacific gas market, a volume of $53.49 \mathrm{bcm}$ is forecasted to be the optimal exporting quantity for Russia. Again, based on Table 8 , this optimal point is attainable because the full exporting potential for Russia by 2020 is around 58 MT or 78.38 bcm. Compared to stage 1, Russia can only increase her volume by $6.17 \%$, probably due to her lack of experience in the LNG market. On the other hand, Qatar, retreating from being the leader to a Cournot player, reduces export by $10.15 \%$ from 137.99 to $123.97 \mathrm{bcm}$. The equilibrium price is

\footnotetext{
${ }^{4}$ Gas companies other than Gazprom.

${ }^{5}$ Relations between the three biggest gas companies are getting tenser when Rosneft and Novatek seek to push Gazprom down from her monopoly position (http://barentsobserver.com/en/energy/2013/04/rosneftnovatek-join-efforts-against-gazprom-26-04).

${ }^{6} 1$ million tons of natural gas $=0.74$ billion cubic meters (based on BP Conversion factors at http://www.bp. com/conversionfactors.jsp).
} 
Table 5 Cost assumptions

\begin{tabular}{lll}
\hline Parameters & Values $(\$ / \mathrm{mmBtu})$ & Source \\
\hline Production cost & $\$ 0.65$ & Cournot-Gandolphe et al. (2003) \\
Liquefaction cost & $\$ 1.05$ & Cournot-Gandolphe et al. (2003) \\
Shipping cost & $\$ 0.60$ & Cournot-Gandolphe et al. (2003) \\
Regasification cost & $\$ 0.40$ & Stauffer (1995) \\
Pipeline transportation cost & $\$ 0.85$ & Brito and Sheshinski (1997) \\
\hline
\end{tabular}

calculated to be $\$ 10.02 / \mathrm{mmBtu}$, an increase of $5.97 \%$ over the first stage. If exporting the optimal volume, Russia can earn a profit of $\$ 11,796,892,12.71 \%$ higher than before while Qatar earns $\$ 38,173,269,460$, an increase of $11.78 \%$ compared to when Qatar is the first mover.

\section{Russia for Asia-Pacific via LNG stage 3}

With plenty of conventional reserves, massive production capacity, established infrastructure, low production costs, and flexibility, Qatar and Russia can undercut the prices offered by other exporters on the same field. Interestingly enough, changing contexts can push these two dominant exporters to cooperate with each other in the Asia-Pacific gas market. ${ }^{7}$ In response to this monopoly state, Asia-Pacific buyers have been pondering upon the collaboration towards a push for delinking gas prices from oil and freeing up contracts that prevent reselling of cargoes. ${ }^{8}$ If this is put forward, a monopsonist structure could be set up to counteract the monopoly exporter.

The price that Russia and Qatar demand is $\$ 11.42 / \mathrm{mmBtu}$ while the price that monopsonist desires to pay is $\$ 4.67 / \mathrm{mmBtu}$. Corresponding to this set of prices, the optimal exporting volume is $150.52 \mathrm{bcm}$ and the optimal import volume is $208.22 \mathrm{bcm}$. The wholesale price would lie in the range of $\$ 3.57-13.9 / \mathrm{mmBtu}$. A breakdown of different parameters in three stages is shown in Table 8.

\section{Qatar for Europe via gas pipeline case 1}

By letting Qatar move the gas up to the European border, as shown in Fig. 2, Turkey receives $\$ 1.8 / \mathrm{mmBtu}$ transit fee for the $17.2 \mathrm{bcm}$ of gas through her territory. The price that Qatar receives from Europe is $\$ 10.7 / \mathrm{mmBtu}$ and that from Turkey $\$ 10.25 / \mathrm{mmBtu}$. With this price charged, Qatar can sell $5.58 \mathrm{bcm}$ to Turkey and earn a total profit of $\$ 4,140,425,250$. It is observed that Turkey would actually pay an effective price of $\$(10.25-1.8) / \mathrm{mmBtu}$ or $\$ 8.45 / \mathrm{mmBtu}$. In comparison with other imports pricing by

\footnotetext{
${ }^{7}$ A clear indication of this possibility is the recent inauguration of Gazprom's representative office in Doha, Qatar (http://english.alarabiya.net/en/views/business/2013/12/01/Will-Qatar-Remain-the-king-of-LNG-.html). ${ }^{8}$ At a conference in Tokyo, Japan has raised her concerns in pushing for oil-delinked gas pricing (http://www. platts.com/latest-news/natural-gas/tokyo/platts-feature-shale-boom-new-projects-boost-27395293).

${ }^{0} 1$ cubic meter $=37.3 \mathrm{mmBtu}$ (from http:/www.investidorpetrobras.com.br/en/services/conversion-tables/ detalhe-formulas-de-conversao/price-conversions-for-natural-gas.htm).
} 
Table 6 Settings of stages/cases and key findings

\begin{tabular}{|c|c|c|}
\hline $\begin{array}{l}\text { Stage/ } \\
\text { scenario } \\
\text { name }\end{array}$ & Setting of stage/scenario & Key findings \\
\hline Russia for & $\begin{array}{c}\text { Asia-Pacific } \\
\text { Via LNG stage } 1\end{array}$ & $\begin{array}{l}\text { Russia follows Qatar in the Stackelberg } \\
\text { game }\end{array}$ \\
\hline $\begin{array}{l}\text { Equilibrium } \\
\text { price is }\end{array}$ & $\begin{array}{l}\$ 9.46 / \mathrm{mmBtu}, \text { Russian optimal quantity is } \\
50.39 \mathrm{bcm}\end{array}$ & \\
\hline Russia for & $\begin{array}{c}\text { Asia-Pacific } \\
\text { Via LNG stage } 2\end{array}$ & Russia is the Cournot player with Qatar \\
\hline $\begin{array}{l}\text { Equilibrium } \\
\text { price } \\
\text { increases } \\
5.97 \% \\
\text { while } \\
\text { Russian } \\
\text { optimal } \\
\text { quantity } \\
\text { increases } \\
6.17 \%\end{array}$ & & \\
\hline Russia for & $\begin{array}{c}\text { Asia-Pacific } \\
\text { Via LNG stage } 3\end{array}$ & $\begin{array}{l}\text { Russia collaborates with Qatar and } \\
\text { importers are a monopsonist }\end{array}$ \\
\hline $\begin{array}{l}\text { Optimal } \\
\text { export } \\
\text { price is }\end{array}$ & $\begin{array}{l}\$ 11.42 / \mathrm{mmBtu} \text { while desirable import price is } \\
\$ 4.67 / \mathrm{mmBtu}\end{array}$ & \\
\hline $\begin{array}{l}\text { Qatar for } \\
\text { Europe } \\
\text { Via pipeline } \\
\text { case } 1\end{array}$ & Qatar moves gas up to the Turkish border & $\begin{array}{l}\text { Qatar charges } \$ 10.7 / \mathrm{mmBtu} \text { to Europe and } \\
\$ 10.25 / \mathrm{mmB} \text { tu to Turkey, transit fee } \\
\$ 1.8 / \mathrm{mmBtu}\end{array}$ \\
\hline $\begin{array}{l}\text { Qatar for } \\
\text { Europe } \\
\text { Via pipeline } \\
\text { case } 2\end{array}$ & $\begin{array}{l}\text { Qatar sells all the gas to Turkey; the leader in the } \\
\text { Stackelberg game with Turkey }\end{array}$ & $\begin{array}{l}\text { Qatar charges Turkey } \$ 9.74 / \mathrm{mmBtu} \text { and } \\
\text { Europe pays } \$ 13.06 / \mathrm{mmBtu}\end{array}$ \\
\hline $\begin{array}{l}\text { Qatar for } \\
\text { Europe } \\
\text { Via pipeline } \\
\text { case } 3\end{array}$ & $\begin{array}{l}\text { Qatar transports gas to the Turkish border; } \\
\text { discriminating pricing applies }\end{array}$ & $\begin{array}{l}\text { Qatar charges Europe } \$ 7.55 / \mathrm{mmBtu} \text { and } \\
\text { charges Turkey } \$ 13.8 / \mathrm{mmBtu}\end{array}$ \\
\hline
\end{tabular}

Turkey, the price paid to Qatar is relatively lower. The import price from Azerbaijan is $\$ 330$ per cubic meter, from Russia is $\$ 400$ per cubic meter, and from Iran is $\$ 505$ per cubic meter (Okumus 2014). These prices converted to $\$ / \mathrm{mmBtu}$ would be $8.85,10.72$, and 13.54 respectively. ${ }^{9}$ From the Turkish point of view, acting as a transit country is beneficial with regard to the prices she has to pay for other options.

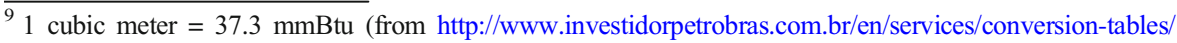
detalhe-formulas-de-conversao/price-conversions-for-natural-gas.htm).
} 
Table 7 LNG projects in Russia

\begin{tabular}{|c|c|c|c|c|c|c|c|c|c|}
\hline \multirow[t]{2}{*}{ Project name } & \multirow{2}{*}{$\begin{array}{l}\text { Destination } \\
\text { market }\end{array}$} & \multirow[t]{2}{*}{ Members } & \multicolumn{6}{|c|}{ Production volumes (millions of tonnes) } & \multirow[t]{2}{*}{ Remarks } \\
\hline & & & 2012 & 2013 & 2016 & 2017 & 2018 & 2020 & \\
\hline Sakhalin-2 & $\begin{array}{l}\text { South-East } \\
\text { Asian } \\
\text { countries }\end{array}$ & $\begin{array}{l}\text { Gazprom, } \\
\text { Royal } \\
\text { Dutch } \\
\text { Shell, } \\
\text { Mitsui, }\end{array}$ & & & & & & & Mitsubishi \\
\hline 10.9 & 10.9 & 10.9 & 10.9 & 10.9 & 10.9 & & & & $\begin{array}{l}\text { Planned } \\
\text { development to } \\
\text { reach up to } 15 \\
\text { million tonnes }\end{array}$ \\
\hline Vladivostok & $\begin{array}{l}\text { South-East } \\
\text { Asian } \\
\text { countries }\end{array}$ & Gazprom & - & - & - & - & 5 & 10 & $\begin{array}{l}\text { Final investment } \\
\text { decision was taken } \\
\text { in Feb 2013, } \\
\text { target output being } \\
15 \text { million tonnes }\end{array}$ \\
\hline Shtokman & - & $\begin{array}{l}\text { Gazprom, } \\
\text { Total }\end{array}$ & - & - & - & - & - & - & $\begin{array}{l}\text { Project suspended, } \\
\text { planned total } \\
\text { output to be } 28-30 \\
\text { million tonnes }\end{array}$ \\
\hline Baltic & $\begin{array}{l}\text { Kaliningrad } \\
\text { Oblast, } \\
\text { European } \\
\text { Union }\end{array}$ & Gazprom & - & - & - & - & 10 & 10 & $\begin{array}{l}\text { Planned capacity is } \\
10 \text { million tonnes, } \\
\text { operation starts in } \\
2018\end{array}$ \\
\hline $\begin{array}{l}\text { Regasification } \\
\text { terminal in } \\
\text { Kaliningrad }\end{array}$ & - & Gazprom & - & - & - & - & 3 & 3 & $\begin{array}{l}\text { Planned output is } 3 \\
\text { million tonnes }\end{array}$ \\
\hline $\begin{array}{l}\text { Sakhalin-1 } \\
\text { (with the } \\
\text { option of } \\
\text { expanding } \\
\text { by Sakhalin } \\
3 \text { and 5) }\end{array}$ & Japan & $\begin{array}{l}\text { Rosneft, } \\
\text { Exxon } \\
\text { Mobil, } \\
\text { ONGC, }\end{array}$ & & & & & & & SODECO \\
\hline- & - & - & - & 5 & 5 & & & & $\begin{array}{l}\text { Target output is } 10 \\
\text { million tonnes }\end{array}$ \\
\hline Pechora & - & $\begin{array}{l}\text { Alltech } \\
\text { Group }\end{array}$ & - & - & - & - & 2.6 & 2.6 & $\begin{array}{l}\text { Target annual output } \\
\text { is } 8 \text { million tonnes }\end{array}$ \\
\hline Yamal & $\begin{array}{l}\text { China } \\
\text { Other }\end{array}$ & & & & & & & & $\begin{array}{l}\text { South-East Asian } \\
\text { countries } \\
\text { European Union }\end{array}$ \\
\hline $\begin{array}{l}\text { Novatek, Total, } \\
\text { CNPC }\end{array}$ & - & - & 5.5 & 11 & 16.5 & 16.5 & & & $\begin{array}{l}\text { Planned annual } \\
\text { capacity is } 16.5 \\
\text { million tonnes }\end{array}$ \\
\hline
\end{tabular}

Source: Kardas (2013b) 
Table 8 Russia for Asia-Pacific via LNG results

\begin{tabular}{llll}
\hline & Stage 1 & Stage 2 & Stage 3 \\
\hline Price $(\$ / \mathrm{mmBtu})$ & 9.46 & 10.02 & - \\
Russia's volume (bcm) & 50.39 & 53.49 & - \\
Qatar's volume (bcm) & 137.99 & 123.97 & - \\
Russia's profit $(\$)$ & $10,466,468,182$ & $11,796,892,359$ & - \\
Qatar's profit $(\$)$ & $34,149,030,787$ & $38,173,269,460$ & - \\
Export price $(\$ / \mathrm{mmBtu})$ & - & - & 11.42 \\
Export volume $(\mathrm{bcm})$ & - & - & 150.52 \\
Import price $(\$ / \mathrm{mmBtu})$ & - & - & 4.67 \\
Import volume $(\mathrm{bcm})$ & - & - & 208.22 \\
\hline
\end{tabular}

\section{Qatar for Europe via gas pipeline case 2}

The second scenario depicts the case where Qatar sells all of her gas to Turkey, consisting of volumes sold to Turkey and to Europe. The inclusion of European gas into one-time transaction with Turkey can help save Qatar the transit tariff. Figure 3 illustrates that in this scenario, the optimal price that Qatar charges Turkey is $\$ 9.74$ / mmBtu for a mass volume of $(5.75+7.77) \mathrm{bcm}$ or $13.52 \mathrm{bcm}$, within which $7.77 \mathrm{bcm}$ would be sold to Europe at a price of $\$ 13.06 / \mathrm{mmBtu}$. Turkey receives a net $\$(13.06$ $-9.74) / \mathrm{mmBtu}$ or $\$ 3.32 / \mathrm{mmBtu}$ and hence a profit of $\$ 689,757,701$ while Qatar's profit is $\$ 2,684,807,537$. Be it in terms of volumes transported, price paid, or profits earned, this scenario is apparently inferior to the first scenario and is not preferred by any party of the game.

\section{Qatar for Europe via gas pipeline case 3}

The volume sold to Turkey significantly reduces when Qatar applies discriminating schemes to destination countries. Turkish import drops from above 5 to $4.4 \mathrm{bcm}$ in the third scenario. On the contrary, Qatar can sell more to Europe than when she has to sell everything to Turkey. The optimal price that Qatar should take from European buyers is $\$ 7.55 / \mathrm{mmBtu}$ and optimal export is $14.7 \mathrm{bcm}$. In opposition to the first scenario, the price that Europe effectively pays is not the same as the price that Qatar receives. When Qatar sets two separate pricing schemes for Turkey and Europe, the price that Europe pays includes an extra component of the transit cost. Abiding by the profit-maximizing rule, as can be seen in Fig. 4, this optimal transit fee is estimated to be $\$ 3.78 / \mathrm{mmBtu}$, and thus the total price faced by European countries is $\$(7.55+3.78) / \mathrm{mmBtu}$ or $\$ 11.33$ / $\mathrm{mmBtu}$. In the last scenario, Qatar pockets $\$ 5,865,977,500,41.6 \%$ in excess of what she earns in case 1 and Turkey gets $\$ 1,855,103,250$. In brief, applying independent prices to her customers may yield Qatar a larger monetary gain. Noticeably enough, Turkey can also benefit from this option with a 2.68 times higher profit than case 2 and 1.8 times higher than case 1 . 
$17.2 \mathrm{bcm}$

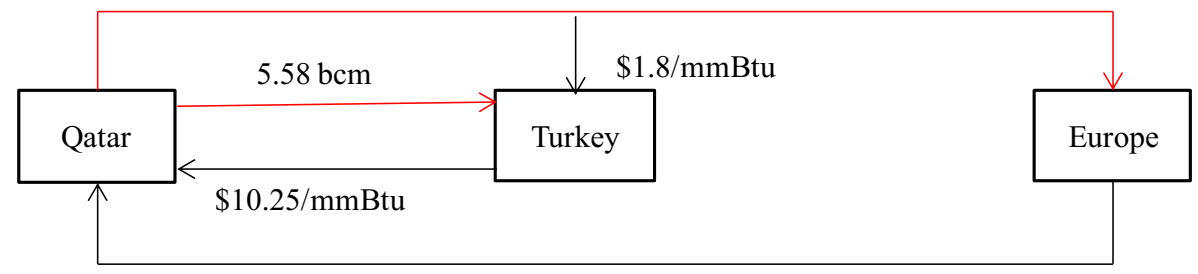

$\$ 10.7 / \mathrm{mmBtu}$

$\begin{array}{lll}\longrightarrow & \text { Volume flow } & \text { Qatar's profit }=\$ 4,140,425,250 \\ \longrightarrow & \text { Monetary flow } & \text { Turkey's profit }=\$ 1,032,172,00\end{array}$

Fig. 2 Qatar for Europe via gas pipeline case 1 results

\section{Sensitivity analyses}

\section{Impact of demand growth on Russia for Asia-Pacific via LNG}

In the Asia-Pacific LNG market, an analysis is conducted to investigate the impact caused on optimal prices when growth rates vary. The equilibrium price of each stage is compared with those under the base case assumption of $25 \%$ for Korea and Taiwan to examine the degree of changes in the rates of growth. ${ }^{10}$ Figure 6 demonstrates the relationship between growth rates and optimal prices in stages 1 and 2 .

When the rate increases, under the Stackelberg game, the price decreases initially, hitting the bottom when the growth reaches $19 \%$ before bouncing back again. In other words, if a growth rate of $19 \%$ is assumed for import demand of Korea and Taiwan, the equilibrium price found is the minimal value. A possible explanation is that as demand rises in the Asia-Pacific, oil-indexing starts to loosen. ${ }^{11}$ The limit of oil-indexing mechanism emerges when Japan's post-Fukushima demand for LNG shoots up, thus raising the LNG spot cargoes' price to record levels. These factors would serve to pull down spot prices when the impact from a surplus of supply kicks in on the gas-to-gas competition.

On the other hand, under the Cournot setting, the critical level of growth rate when price makes a turning point is $26 \%$, which is higher than our assumption. At this stage, when some gas fields in Russia are fully commissioned, the abundant supply flowing to the Asia-Pacific market can sustain the drop in price longer as demand creeps up. A more detailed examination at the prospective supply source suggests that the intended expansion of Vladivostok's second train in 2020 serves as an unrivalled opportunity to gain a stronger access to the promising emerging Asia-Pacific (Markelov 2013). It is

\footnotetext{
${ }^{10}$ In this paper, base case scenario for Russia-Asia Pacific game is optimistically projected to be the highdemand growth for imported LNG in Korea and Taiwan.

${ }^{11}$ When Korea and China started their imports of LNG in the late 1980s, the fact that their supply contracts were linked to JCC made it the dominant marker of gas prices. The plunge in oil prices afterwards necessitates the S-curve pricing formula. S-curve formula makes sure that the relationship between gas and oil prices only holds when oil prices move within a predetermined range. When oil prices fall out of this range, the link would be weakened to protect the abrupt changes in gas prices.
} 


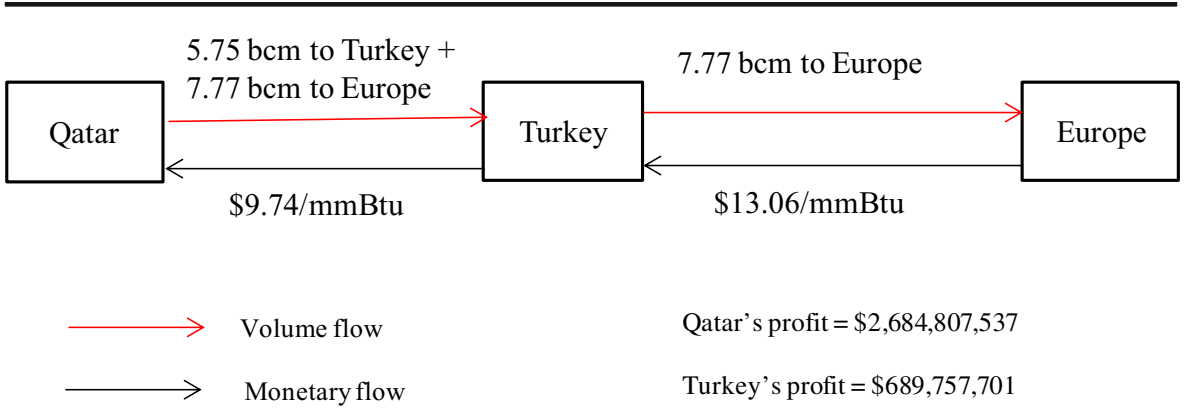

Fig. 3 Qatar for Europe via gas pipeline case 2 results

also remarkable that at every rate of growth, the optimal Cournot price is always higher than the Stackelberg price. This seems to be in stark contrast with the theory, in which the Cournot is supposed to be a fair game without prior knowledge of competitors' moves while the Stackelberg game is built on the understanding that follower's quantity is factored in the leader's production decision. Indeed, the underlying intuition is that the development of Russia's capabilities can offer buyers a wider supply choice. Hence, it may substantially reduce Qatar's volumes, resulting in a fall in volume overall and lifting the equilibrium price curve above that of stage 1 . This pattern does not last long throughout. As illustrated in Fig. 5, the gap between these two prices diminishes as the extent of growth increases, i.e., the contradiction tends to fade away.

Based on the aforementioned context, the setup of a monopsonist on Asian buyers is in response to a hike in import price and the potential alliance of exporters which can further feed on the increase in price. As shown in Fig. 6, the maximum price decreases slightly when demand growth is less than $13 \%$. When demand is above this threshold, an increase in growth rate raises optimal price. It is apparent that as consumers are purchasing more, given the immense market size, people are affordable to pay more. Meanwhile, the minimum price tends to climb up over an ascending range of growth

$14.7 \mathrm{bcm}$

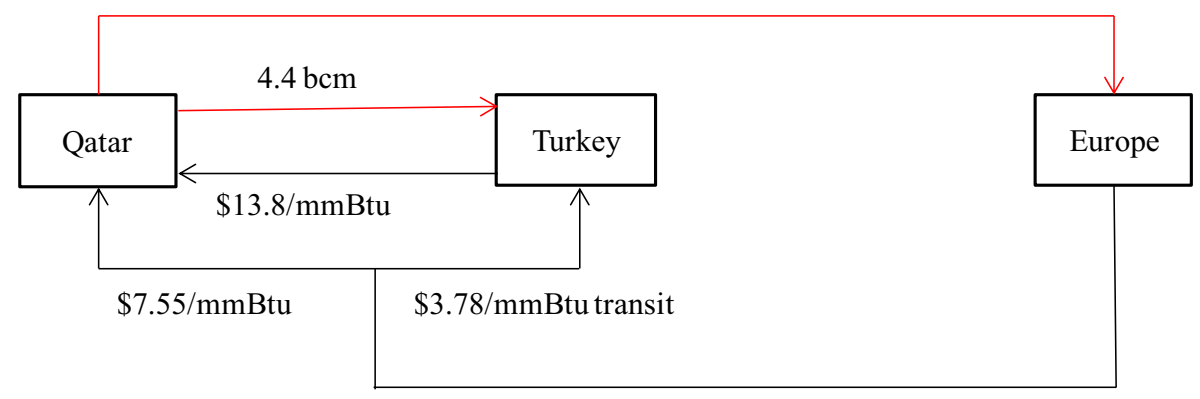

$\$ 11.33 / \mathrm{mmBtu}=\$(7.55+3.78) / \mathrm{mmBtu}$

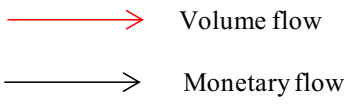

Fig. 4 Qatar for Europe via gas pipeline case 3 results 
rates. This could be because in order to supply a swelling market, exporters demand more for the minimum price that they can get.

\section{Impact of capacity expansion on Qatar for Europe via gas pipeline}

According to Centre for Middle Eastern Strategic Studies (2011), the planned pipeline from Qatar to Turkey is expected to be $550 \mathrm{~km}$ long in the sea pillar and have an initial capacity of $20 \mathrm{bcm}$ annually. Therefore, if the assumption of $15 \mathrm{bcm}$ capacity reserved for Turkey and European buyers is relaxed, any potential volume from 15 to $20 \mathrm{bcm}$ could be factored in. The impact of varying capacity of Qatar's proposed pipeline compared to the base case results is laid out in Table 9. It is noted that as the volume transported to Turkey and Europe is raised to $16 \mathrm{bcm}$, the optimal price that Qatar charged to Europe rises $26 \%$ in case 3 and only $16 \%$ in case 1 . As this capacity is being expanded, the percentage change in price for case 3 is always at least as much as case 1 , confirming the superiority of multi-pricing strategy of Qatar.

However, this adjustment of volume does not seem to affect the price that Qatar asks from Turkey. One possible reason is that the Turkish price only depends on her country's demand elasticity rather than what Qatar has to offer while the European price is estimated from the profit-maximizing condition of Qatar. From Turkey's welfare benefits, being a well-known energy hub by ensuring supply security and actively seeking for more transit revenues, Turkey would be more than welcome to partner with Qatar if the prerequisite of the pliable regime in Syria is gotten through. ${ }^{12}$

Table 9 also indicates that as Qatar is able to transport more gas to Europe by 2025, optimal transit fees increase more substantially under case 1 than case 3 . Under base case results, since Qatar can only sell $4.4 \mathrm{bcm}$ to Turkey, the crowding-out effect of a two-pricing strategy in case 3 pulls out a greater volume out of Turkey compared to case 1 . Eventually, the estimated transit fee compensated is higher in magnitude and the final marginal change from capacity upgrade is smaller.

All in all, including the analysis of base case and sensitivity results, a tactic move for both Qatar and Turkey in routing Qatari gas to Europe is when Qatar charges different prices for Turkish and European buyers. An enlargement in the volumes moved to Turkey would create an upside movement in the price that Qatar can get from the prolific Europe market.

\section{Conclusion}

This paper analyzes how Russia and Qatar behave in hypothetical scenarios where they diversify their sources of demand, if the competitive landscape today persists, or otherwise in collusive outcomes. The paper adopts a game-theoretical approach to examine the hypothetical scenarios between Russia, the largest exporter of pipeline gas, and Qatar, the largest exporter of LNG. The paper found that various factors determine the most preferable scenarios for Russia and Qatar.

\footnotetext{
${ }^{12}$ It is widely known that by dint of her geography, Turkey has substantial maneuver ability in negotiating over different pipeline contracts from Iraq, Russia, and Qatar. In spite of that, projects from Russia and Iraq are hard to realize due to the political unrest in these regions (Dietl 2013).
} 


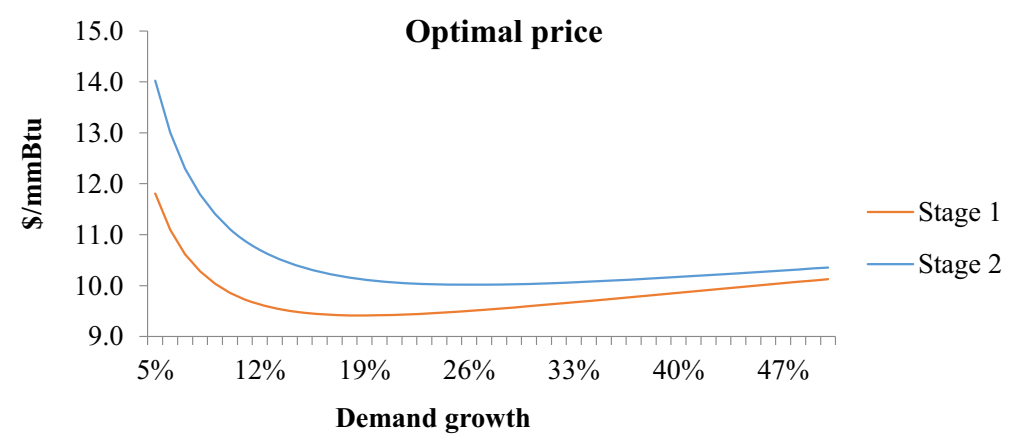

Fig. 5 Impact of varying demand growth rates on optimal price in stage 1 and stage 2

In the first of three stages, in which Russia delivers gas to the Asia-Pacific LNG market, it is found that Russia's profit is much lesser than that of Qatar's, assuming that Russia follows Qatar within a Stackelberg game framework. This situation persists as the game proceeds into its second stage, where Russia and Qatar enter into a Cournot game setting. However, both Qatar and Russia have increased profits a bit. Russia appears to set about a $6 \%$ higher price in the Cournot game as compared to one in the Stackelberg game, and the price for the third and last stage lies within the range of about $\$ 5$ and $\$ 12$. When Qatar is determined to transport gas to the European border via transit countries, the multi-pricing scheme appears to yield Qatar of about $\$ 6000$ million. For this circumstance, European consumers have to pay about $\$ 12 / \mathrm{mmBtu}$.

When sensitivity analyses are carried out, the demand growth rates for Asia-Pacific LNG import charges, the calculation reveals that price decreases initially and reverses when the growth rate reaches $19 \%$ in the Stackelberg game. In the Cournot setting, the minimum price point occurs at a $26 \%$ growth rate. When a bilateral monopoly is formed, the maximum price decreases slightly when demand growth is less than $13 \%$. When demand is above this threshold, an increase in growth rate will correlate with the upward trending of optimal prices. For pipeline gas market in Europe, it is noted that as the volume transported to Turkey and Europe is raised to 16 billion cubic meters, the optimal price that Qatar should charge to Europe rises 26\% relative to discriminating prices and only $16 \%$ when she transports gas to the European border.

It is not the intention of this paper to provide support for specific policies. The findings of this paper are aimed at providing an understanding of the equilibrium

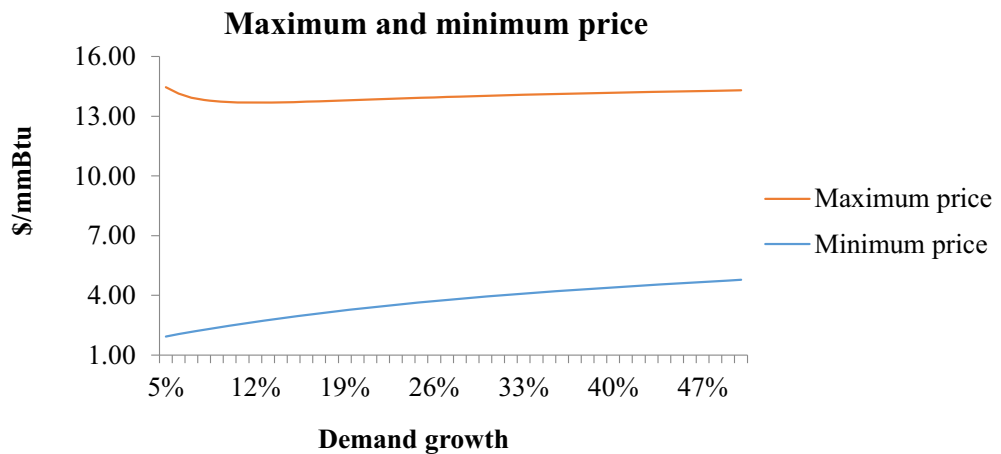

Fig. 6 Impact of varying demand growth rates on the maximum and minimum price in stage 3 
Table 9 Sensitivity results of varying capacity expansion of Qatar pipeline on Qatar-Europe game (compared to base case)

\begin{tabular}{|c|c|c|c|c|c|c|}
\hline \multirow[t]{2}{*}{ Change in the following over base case } & \multirow{2}{*}{$\begin{array}{l}\text { Unit } \\
\text { bcm }\end{array}$} & \multicolumn{5}{|c|}{ Capacity expansion by 2025} \\
\hline & & 16 & 17 & 18 & 19 & 20 \\
\hline \multirow[t]{2}{*}{ Case 1 optimal price to Europe } & $\$ / \mathrm{mmBtu}$ & 14.20 & 14.95 & 15.58 & 16.08 & 16.45 \\
\hline & $\%$ & 33 & 40 & 46 & 50 & 54 \\
\hline \multirow[t]{2}{*}{ Case 1 optimal price to Turkey } & $\$ / \mathrm{mmBtu}$ & 10.25 & 10.25 & 10.25 & 10.25 & 10.25 \\
\hline & $\%$ & 0 & 0 & 0 & 0 & 0 \\
\hline \multirow[t]{2}{*}{ Case 1 optimal transit fee } & $\$ / \mathrm{mmBtu}$ & 4.18 & 5.20 & 6.21 & 7.22 & 8.22 \\
\hline & $\mathrm{x}$ & 2.32 & 2.89 & 3.45 & 4.01 & 4.57 \\
\hline \multirow[t]{2}{*}{ Case 2 optimal price to Turkey } & $\$ / \mathrm{mmBtu}$ & 13.67 & 15.04 & 16.16 & 17.10 & 17.89 \\
\hline & $\%$ & 5 & 15 & 24 & 31 & 37 \\
\hline \multirow[t]{2}{*}{ Case 3 optimal price to Turkey } & $\$ / m m B t u$ & 13.8 & 13.8 & 13.8 & 13.8 & 13.8 \\
\hline & $\%$ & 0 & 0 & 0 & 0 & 0 \\
\hline \multirow[t]{2}{*}{ Case 3 optimal price to Europe } & $\$ / \mathrm{mmBtu}$ & 9.55 & 10.55 & 11.55 & 12.55 & 13.55 \\
\hline & $\%$ & 26 & 40 & 53 & 66 & 79 \\
\hline \multirow[t]{2}{*}{ Case 3 optimal transit fee } & $\$ / \mathrm{mmBtu}$ & 4.78 & 5.28 & 5.78 & 6.28 & 6.78 \\
\hline & $\mathrm{x}$ & 1.26 & 1.40 & 1.53 & 1.66 & 1.79 \\
\hline
\end{tabular}

outcomes under a game-theoretical framework, and the distributional effects for each country. Overall, the expectations of price and quantity movements in each scenario suggest that for Russia to compete in the LNG market, cooperation with Qatar is likely. In maximizing profits, Russia and Qatar will serve as monopolies in their regional markets and address their respective segmental demand. It is also found that profits are maximized for Qatar and Turkey under a differential pricing scheme where export is whole to Turkey, as shown in the "Qatar for Europe via gas pipeline case 3" section.

The specifications in the adopted scenarios in the game-theoretical setting allow for simulating various cases that might be more realistic in the future. This paper could be a good starting point for exploring implications of market interactions between exporters and importers of natural gas in the world market.

\section{References}

Aune, Finn Roar, Rosendahl KE, Sagen EL (2008) Globalization of natural gas markets - effects on prices and trade patterns, Research Department of Statistics Norway. Discussion paper No. 559

Boersma T (2013) Four questions on shale gas development in Europe and the US. Opinion, Brookings

British Petroleum (2020) BP statistical review of world energy

Brito DL, Hartley PR (2007) Expectations and the evolving world gas market. Energy J 28(1):1-24

Brito Dagobert L, Sheshinski E 1997 Pipelines and the exploitation of gas reserves in the Middle East, Energy Forum study on "Political, Economic, Social, Cultural, and Religious Trends in the Middle East and the Gulf and Their Impact on Energy Supply, Security, and Pricing” 
Brown SPA, Yucel MK (2009) Market arbitrage: European and North American natural gas prices. Energy J 30(Special issue):167-186

Chernavsky S, Eismont O (2012) How to sell Russian gas to Europe via Ukraine? OPEC Energy Review 36(1):87-103. https://doi.org/10.1111/j.1753-0237.2011.00203.x

Cournot-Gandolphe S, Appert O, Dickel R, Chabrelie MF, Rojey A (2003) The challenges of further cost reductions for new supply options, 22nd edn. World Gas Conference, Japan

Das DK (2011) Issues facing US shale gas exports to Japan. The Pipeline and Gas Journal 238(12)

Dietl Gulshan (2013) Will Turkey be the new hub for gas?, Institute for Defence Studies and Analyses

Dorigoni S, Graziano C, Pontoni F (2009) Can LNG increase competitiveness of the natural gas market? Energy Policy 38(2010):7653-7664

Egging RG, Gabriel SA (2016) Risks in global natural gas markets: investment, hedging and trade. Energy Policy 94:468-479

Egging R, Holz F, von Hirschhausen C, Gabriel SA (2009) Representing GASPEC with the World Gas Model. Energy J 30 (Special issue)

Energy Information Administration (EIA) (2020) Henry Hub Natural Gas Spot Price. Available at https:// www.eia.gov/dnav/ng/hist/rngwhhdm.htm

Ernst and Young (2013) Global LNG trends. Baku, Azerbaijan

Hartley PR, Medlock KB III (2009) Potential futures for Russian natural gas exports. Energy J 30(Special issue):73-96

Henderson James 2012 The potential impact of North American LNG exports, Oxford Institute for Energy Studies, NG 68

Holz F, von Hirschhausen C, Kemfert C (2009) Perspectives of the European natural gas markets until 2025. Energy J 30(Special issue):137-150

IEA (International Energy Agency) 2010 World Energy Outlook

IEA (International Energy Agency) 2011, World Energy Outlook. Special report "Are we entering a golden age of gas?"

IGU (International Gas Union) 2018 IGU World Gas LNG Report - 27 th World Gas Conference Edition

Kardas Szymon 2013a, Russia activates the LNG sector, Centre for Eastern Studies (OSW), Analyses, 2013$01-16$

Kardas Szymon 2013b A feigned liberalisation: Russia is restricting Gazprom's monopoly on exports Centre for Eastern Studies (OSW), Commentary, Number 121. Available at http://www.osw.waw.pl/sites/ default/files/commentary_121_0.pdf

Komiyama R, Zhidong L, Ito K (2005) World energy outlook in 2020 focusing on China's energy impacts on the world and Northeast Asia. International Journal of Global Energy Issues 24(3/4):183-210. https://doi. org/10.1504/IJGEI.2005.007770

Kovacevic Aleksandar 2009 The impact of the Russian-Ukraine gas crisis in South Eastern Europe, Oxford Institute for Energy Studies, NG 29. Available at http://www.oxfordenergy.org/wpcms/wp-content/ uploads/2010/11/NG29-TheImpactoftheRussiaUkrainianCrisisinSouthEasternEuropeAleksandarKovacevic-2009.pdf (access on 9 Mar 2014).

Li R, Joyeux R, Ripple RD (2014) International natural gas market integration. Energy J 35(4):159-179

Lise W, Hobbs BF (2009) A dynamic simulation of market power in the liberalised European natural gas market. Energy J 30(Special issue):119-135

Lochner S, Dieckhöner C (2010) Tiger: infrastructure and dispatch model of the European gas market, Institute of Energy Economics at the University of. Cologne, Cologne

Markelov Vitaly 2013 Vladivostok LNG project very attractive for consumers and investors, Presentation on October 22, 2013 on Russky Island

Nesbitt DM, Scotcher JN (2009) Spatial price and quantity relationship in world and continental commodity market. Energy J 30(Special issue):21-38

Neumann A (2009) Linking natural gas markers: is LNG doing its job? Energy J 30(Special issue):187-200

Okumus Olgu 2014 Why is Turkey buying more gas than it needs from Iran? Al-Monitor. Available at http:// www.al-monitor.com/pulse/originals/2014/02/turkey-iran-gas-import-consumption-erdogan-price.html\#

Orlov A (2015) An assessment of optimal gas pricing in Russia: a CGE approach. Energy Econ 49:492-506

ORSAM (Centre for Middle-Eastern strategic studies) (2011) Is the Qatar-Iraq-Turkey-Europe natural gas pipeline project feasible? (Report no. 23). Ankara, Turkey

Popescu M, Hurduzeu G (2015) Energy challenges for Europe - scenarios of the importance of natural gas prices from a game theory perspective. Journal of Game Theory 4(2):26-35

Rasoulinezhad E, Taghizadeh-Hesary F, Yoshino N, Sarker T 2019 Russian Federation-East Asia liquefied natural gas trade patterns and regional energy security. ADBI Working Paper 965. Tokyo: Asian 
Development Bank Institute. Available: https:/www.adb.org/publications/russian-federation-east-asialiquefied-natural-gas-tradepatterns-security

Ratner Michael, Belkin P, Nichol J Woehrel S 2013 Europe's energy security: options and challenges to natural gas supply diversification, Congressional Research Service. Available at http://www.fas.org/sgp/ crs/row/R42405.pdf (access on 9 Mar 2014)

Reuters 2019 U.S. wants Qatar to challenge Russian gas in Europe - U.S. official. Retrieved from https:// www.reuters.com/article/usa-energy-gulf/us-wants-qatar-to-challenge-russian-gas-in-europe-us-officialidUSL8N1ZE1XG

Reuters 2020 GLOBAL LNG-Asian LNG prices fall to $\$ 2.70 / \mathrm{mmBtu}$ amid coronavirus outbreak. Retrieved from https://www.reuters.com/article/global-lng/global-lng-asian-lng-prices-fall-to-2-70-mmbtu-amidcoronavirus-outbreak-idUSL4N2AE2BM

Rogers Howard V, 2012 The impact of a globalising market on European gas supply and pricing: the importance of Asian demand and North American supply, Oxford Institute for Energy Studies, NG 59

Stauffer TR (1995) The diseconomies of long-haul LNG trading. The Journal of Energy and Development 20(2):159-174

United Nations Conference on Trade and Development (UNCTAD) 2018. Commodities at a glance: special issue on shale gas

von Hirschhausen C, Meinhart B, Pavel F (2005) Transporting Russian gas to Western Europe - a simulation analysis. Energy J 26(2):49-68

Wood DA (2012) A review and outlook for the global LNG trade. Journal of Natural Gas Science and Engineering 9:16-27. https://doi.org/10.1016/j.jngse.2012.05.002

World Oil 2020 Global oversupply sets up LNG for a year of record low prices. Retrieved from https:/www. worldoil.com/news/2020/1/24/global-oversupply-sets-up-lng-for-a-year-of-record-low-prices

Xiao J, Kong W, Wang X, Li M (2019) Numerical modelling and assessment of natural gas pipeline separation in China: the data from Henan Province. Pet Sci 17:268-278

Xinhua 2019 China-Russia east-route natural gas pipeline in operation. Retrieved from http://www.xinhuanet. com/english/2019-12/02/c 138600270.htm Feb 2020

Zhu Q, Ding L, Wu Y, Zuo R (2018) Trends in the natural gas pricing mechanism reform in China: a perspective of dependency between China and the US natural gas market. Int J Internet and Enterprise Management 9(1):40-57

Zwart Gijsbert 2008 European natural gas markets: resource constraints and market power, TILEC Discussion Paper no. 2008-043. Available at SSRN: http://ssrn.com/abstract=1310688 or https://doi.org/10.2139/ Ssrn. 1310688

Publisher's note Springer Nature remains neutral with regard to jurisdictional claims in published maps and institutional affiliations. 